\begin{tabular}{|c|c|c|}
\hline $\begin{array}{l}\text { SOUDNÍ } \\
\text { INŽENYRSTI }\end{array}$ & $\begin{array}{c}\text { Ročnik } 30 \cdot 2 / 2019 \\
\text { Znalecká činnost } ・ \text { Expert Activity } \\
\text { www.soudniinzenyrstvi.cz }\end{array}$ & 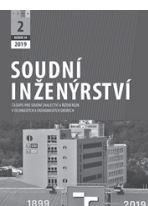 \\
\hline
\end{tabular}

\title{
Rovnovážné a mezní stavy v bezpečnosti a soudním inženýrství
}

\author{
Equilibrium and Limite States in Security and Forensic Engineering
}

Roman $\mathrm{Rak}^{*}$

VŠFS, Katedra kriminalistiky a forenznich disciplín

\begin{abstract}
Abstrakt
Pro potřeby analýzy rizik a zajišt'ování bezpečnosti jsou definovány základní termíny jako je jev, událost, děj, stav, situace. K dalším významným pojmům patř́i pojmy rovnováha, rovnovážný stav, rovnovážná poloha, rovnováha sil a stabilita (nestabilita, labilita). S těmito termíny se můžeme setkat jak v bezpečnosti, tak i v technických, ale i ekonomických a společenských vědách. Tento př́spěvek obecně vymezuje a vysvětluje tyto klíčové pojmy např́íc různými vědními obory či obory lidské činnosti. Příspěvek byl prezentován na Mezinárodní vědecké konferenci ExFoS 2019 v Brně.
\end{abstract}

Klíčová slova: rovnováha, rovnovážný stav, rovnovážná poloha, rovnováha sil a stabilita.

\section{1. ÚVOD}

Žijeme ve světě, který se neustále rozvíjí. V oblastech lidského poznání, vědy, techniky, ekonomiky i ve společnosti. Současný rozvoj je ale plný napětí a konfliktů, ve všech zmíněných oblastech. Stranou nezůstává oblast technická, ekonomická, sociální či politická, které jsou často příčinou i „konzumentem“ různých negativních dopadů, včetně dopadů do bezpečnosti [1], [7], do bezpečí.

Život nás učí i nutí určovat každodenní hrozby v rozmanitých oblastech lidských činností, stanovovat a oceňovat rizika a ty následně různými způsoby a technikami řídit, aby nedocházelo k ohrožení chráněných aktiv, škodám či újmám.

Aby výše uvedený proces byl efektivní, je nutné pochopit podstatu, vlastnosti, chování či zákonitosti dílčích objektů a procesů, které vstupují do různých vazeb a interakcí, které následně ovlivňují a determinují chování velkých celkủ či systémů.

Reálně i podvědomě rozdělujeme vědu i veškeré procesy či dění do čtyř základních oblastí: prrírodovědných, technických, ekonomických a sociálně společenských. Současná doba nás stále více a více nutí, abychom se na náš svět dívali „,spojitě“, prizmatem všech čtyř oblastí, protože jedině tak můžeme dlouhodobě

\begin{abstract}
Basic terms such as phenomenon, event, state, situation are defined for risk analysis and security needs. Other important terms include, equilibrium and stability (instability, lability). These terms can be found in both security and technical sciences as well as economic and social sciences. This paper generally defines and explains these key concepts across different disciplines or fields of human activity. The paper had been presented at the International scientific conference ExFoS 2019 in Brno.
\end{abstract}

Keywords: equilibrium, equilibrium, equilibrium position, balance of forces and stability.

garantovat tzv. „udržitelný rozvoj“, který má i své bezpečnostní aspekty.

K významným pojmům patři pojmy rovnováha, rovnovážný stav, rovnovážná poloha, rovnováha sil a stabilita (nestabilita, labilita). Tyto pojmy určují, zda se různé entity budou dále zdárně, kontinuálně vyvíjet, nebo zda bude docházet k různým krizím, mimořádným stavům, stagnacím apod., se všemi jejich vyplývajícími vlastnostmi, důsledky. Kromě toho, že potřebujeme poznat vlastnosti, vztahy a chování jednotlivých objektů či procesů, abychom je mohli pochopit a následně řídit, musíme chápat jejich rovnovážné a mezní stavy, které vždy určují kritické hranice následného rozvoje mimořádných, nechtěných událostí.

\section{ROVNOVÁHA, ROVNOVÁŽNÝ STAV, ROVNOVÁŽNÁ POLOHA, STABILITA (BALANCE, EQUILIBRIUM STATE, EQUILIBRIUM POSITION, STABILITY)}

Je obecně známo, že pokud se objekty, systémy či procesy, události, děje [16], [18] nacházejí v rovnováze, rovnovážném stavu, rovnovážné poloze a mají schopnost stability, jsou v určitém 
smyslu v průběhu času bezpečné, tj. nebývají s nimi žádné neočekávané bezpečnostní incidenty, události, děje; chovají se tak, jak jsme předpokládali (navrhovali, projektovali, vyráběli, testovali apod.). Teprve po ztrátě rovnováhy, rovnovážného stavu, rovnovážné polohy a následně stability dochází k bezpečnostním událostem, incidentům, při kterých dochází ke škodám či újmám [25]. Rovnovážný stav a stabilita jsou proto další důležité charakteristické vlastnosti objektů, systémů či procesů, které rozhodují o jejich chování z hlediska bezpečnosti [22].

Pojmy rovnováha, rovnovážný stav, rovnovážná poloha, rovnováha sil a stabilita nejsou obecně definovány, ale zpravidla jejich definice jsou účelově zaměřené do určitých profesních oblastí. Synonymem slova stabilita jsou stabilnost, ustálenost, rovnovážnost, rovnováha nebo stálost, stálost vlastností, trvalost, pevnost. Rovnováha znamená obecně „být v souladu“, „být vzájemně vyrovnaný“". Antonymem stability je labilita.

\section{Stálá rovnovážná poloha}

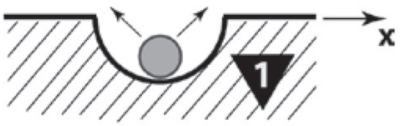

Vratká rovnovážná poloha

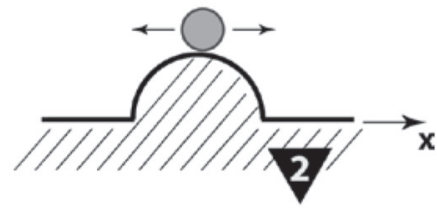

Volná rovnovážná poloha

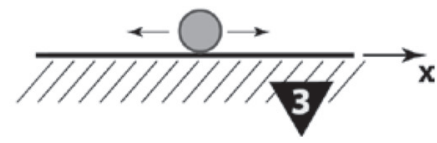

Obr. 1 Názorné zobrazení rovnovážných poloh v mechanice těles.

Fig. 1 Illustrative representation of equilibrium positions in solid mechanics.

\subsection{Rovnováha (Balance, equilibrium)}

Rovnováha je obecně stav systému, kdy je působení všemi směry vzájemně vyrovnáno. Pojem rovnováha může mít více významů.

$\mathrm{S}$ pojmem rovnováhou sil se setkáváme $\mathrm{v}$ různých oblastech, jako je vojenství, ekonomika, podnikání, sport apod. Pod silami si můžeme představit síly př́rodní, fyzikální, vojenské, politické, společenské, náboženské, nepřátelské, kriminální (živly) apod.

Pod rovnováhou sil rozumíme vyváženost, která obecně vede ke stabilitě. Všechny síly jsou vyvážené, tj. žádná síla „nepřevládá nad ostatními silami“.

\subsection{Rovnovážná poloha (Equilibrium position)}

Ve fyzice (mechanice) je rovnovážná poloha definována jako poloha tuhého tělesa, při níž je výslednice všech sil působících a těleso nulová a výsledný moment všech sil je také nulový. Rovnovážná poloha je poloha, která je výsledkem rovnováhy sil.

Platí i naopak:

Rovnováha sil je stav, kdy na těleso působí více sil, ale jejich výslednice je nulová, a výsledný moment sil vzniklý složením všech momentů sil je rovněž nulový.

Rozlišujeme (v mechanice) tř̌i základní rovnovážné polohy:

- Stálá rovnovážná poloha (též stabilní rovnovážná poloha) je poloha, pro kterou platí, že po vychýlení z této polohy se těleso vrací zpět, tzn. vychýlení se postupně zmenšuje. Potenciální energie tělesa ve stálé rovnovážné poloze je nejmenší, při vychýlení se zvětšuje.

Přikladem může být kulička nacházejíci se v důlku. Při vychýleni se kulička bude vracet zpět do výchozi pozice. Při vychýlení se zvyšuje potenciální energie kuličky.

- Vratká rovnovážná poloha (též labilní rovnovážná poloha) je poloha, pro kterou platí, že po vychýlení z této polohy se těleso nevrací zpět, ale výchylka se dále zvětšuje. Vychýlením z vratké polohy se potenciální energie tělesa zmenšuje.

Př̉kladem může být kulička nacházejicí se na vrcholu kopce. Při vychýlení ze své pozice se kulička bude vždy kutálet dolì a sama se nevrátí na výchozi pozici. Při vychýlení se snižuje potenciální energie kuličky.

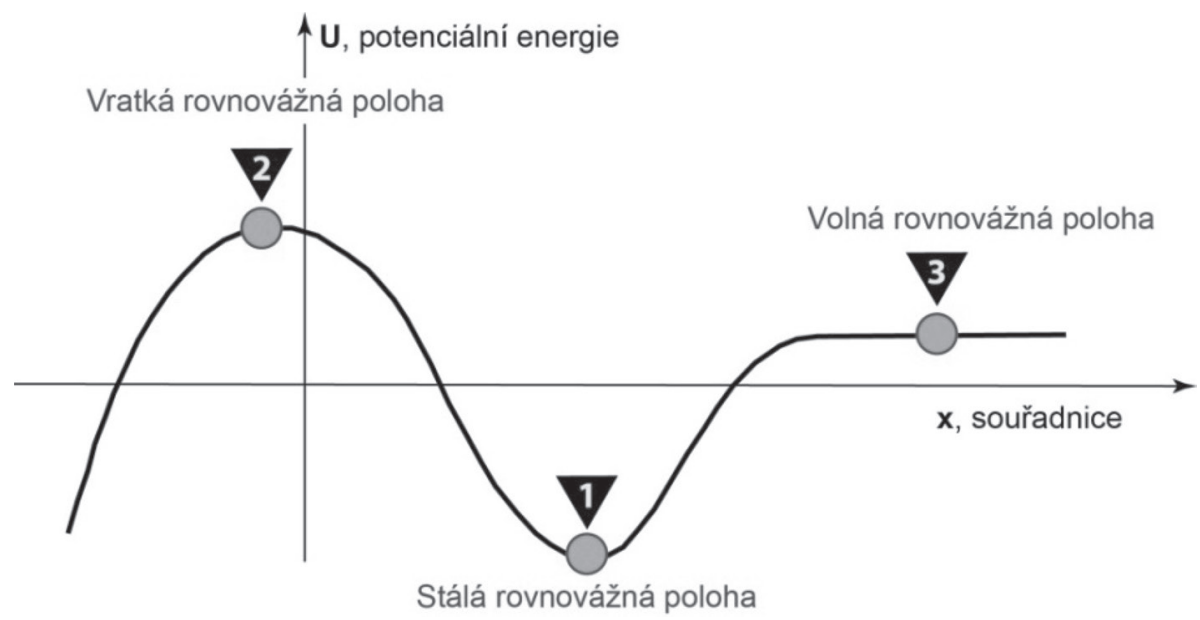

Obr. 2 Závislost potenciálni energie U na souřadnici x kuličky při jejím přechodu z rovnovážné polohy vratké do stabilní a dále pak do volné rovnovážné polohy.

Fig. 2 The dependence of potential energy $U$ on the $x$ coordinate of the ball when it moves from the equilibrium position to the stable and then to the free equilibrium position. 


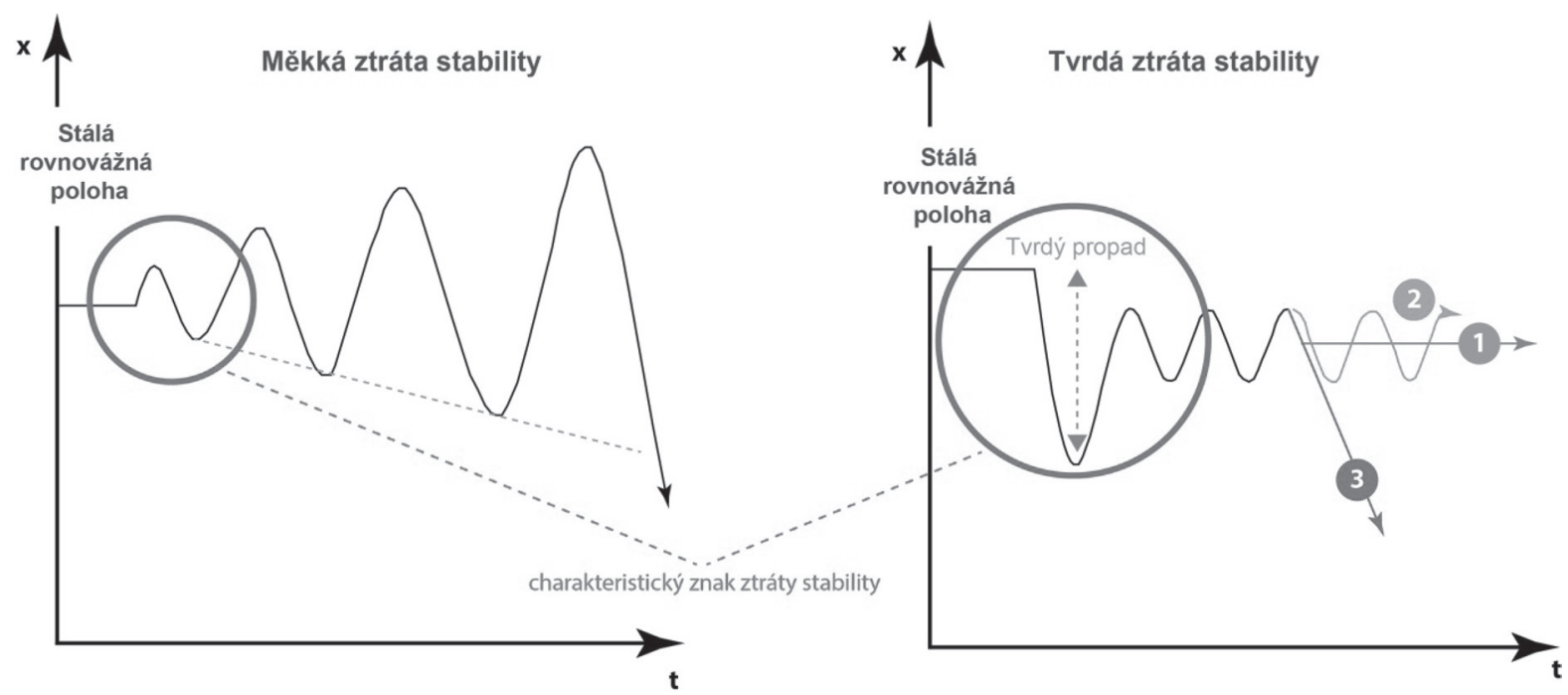

Obr. 3 Srovnáni měkké a tvrdé ztráty stability v čase.

Fig. 3 Comparison of soft and hard loss of stability over time.

- Volná rovnovážná poloha (též indiferentní rovnovážná poloha) je poloha, pro kterou platí, že vychýlením tělesa se výslednice sil ani výsledný moment síly působících na těleso nemění. Po vychýlení tělesa se vzdálenost od nové polohy nemění (nezmenšuje se ani se nezvětšuje). Při vychýlení tělesa zůstává potenciální energie konstantní. Př́kladem může být kulička nacházejici se na vodorovné rovině. Posuneme-li kuličku na jiné misto, zuistane tam stát a nebude se od pưvodní polohy ani vzdalovat, ani se k ni nebude vracet. Potenciálni energie zůstává konstantní.

\subsection{Rovnovážný stav (Equilibrium state)}

$\mathrm{V}$ termodynamice je rovnovážný stav definován jako takový stav termodynamického systému, kde neprobíhají žádné toky extenzivních veličin (tepla, hmoty, energie apod.). Intenzivní veličiny často bývají v tomto př́padě v celém systému stejné.

Jeden z postulátů termodynamiky uvádí, že každý systém dosáhne rovnovážného stavu. Každý systém, který se nachází od určitého okamžiku v neměnných vnějších podmínkách, přejde samovolně po určité době do rovnovážného stavu. V tomto stavu setrvává, pokud zůstanou vnější podmínky zachovány.

Výše uvedené tvrzení je obecné, platí jak pro př́rodní, tak pro společenské, politické [20], [21] atd. rovnovážné stavy, které jsou charakteristické pro objekty, systémy a procesy. V procesu každého vývoje, evoluce atd. dochází pravidelně, v různě dlouhých časových úsecích ke změnám rovnovážných stavů, ke ztrátě stability a následně $\mathrm{k}$ vytvoření nového rovnovážného stavu. Ze společenského, lidského, či bezpečnostního hlediska je vždy otázka, zda nový, rovnovážný stav je pro nás žádoucí („,musí nám nutně vyhořet dům, abychom si postavili nový?“). V některých (mnoha!) případech bezpečnostního charakteru je zpravidla nežádoucí, aby došlo ke ztrátě stability současného objektu, systému či procesu [3], [7].

Každý stav, každý rovnovážný stav můžeme charakterizovat pomocí pro něj charakteristických, významných parametrů, veličin. Jakákoliv změna parametru, který je pro rovnovážný stav (objektu, systému či procesu) významný, může narušit rovnovážný stav a vést ke ztrátě stability [4].

Ztráta stability rovnovážných stavů je přirozeným jevem, který je součástí antagonistického světa, evolučního i revolučního vývoje [5]. Tendenci ztráty stability rovnovážných stavů je sice možné subjekty pomocí určitých opatření do značné míry snížit preventivními nástroji, $\mathrm{v}$ převážné většině př́ípadů není možné ztrátě stability zabránit [24]. Ztrátu stability rovnovážného stavu je možné podle jejího průběhu dělit na dva základní druhy [24]:

- měkká ztráta stability,

- tvrdá ztráta stability.

Touto problematikou se zabývá zejména matematická „teorie katastrof", kterou v minulém století rozpracovali ruský matematik Vladimir Igorevich Arnold (1937-2010) a francouzský matematik a filosof René Frédéric Thom (1923-2002) a zejména Sir Erik Christopher Zeeman (1925-2016).

\subsubsection{Měkká ztráta stability (Soft loss of stability)}

$\mathrm{V}$ př́padě měkké ztráty stability se ustáleným režimem systému stává oscilující periodický režim, který se ve svém počátku málo liší od rovnovážného stavu. První symptomy narušení stability nemusejí být zpočátku vůbec pozorovatelné, vznikají pomalu, postupně. Postupná změna parametrů ale $\mathrm{v}$ konečném důsledku může způsobit ztrátu stability systému [24].

\subsubsection{Tvrdá ztráta stability (Hard loss of stability)}

Náhodné nebo záměrně okamžité a zásadní změny parametrů a jejich projevy narušení funkčnosti systému natolik, že se úplně naruší stabilita, se nazývá tvrdá ztráta stability systému. Systém opouští rovnovážný stav skokem a přechází na jiný režim vývoje. Může to být jiný stabilní stacionární režim, stabilní oscilace kolem rovnovážného stavu ale též složitější nerovnoměrný pohyb [24].

\subsection{Stabilita (Stability)}

Ve fyzice (mechanice) je stabilita definována jako rozdíl potenciální energie tělesa mezi vratkou a stálou rovnovážnou polohou, neboli 

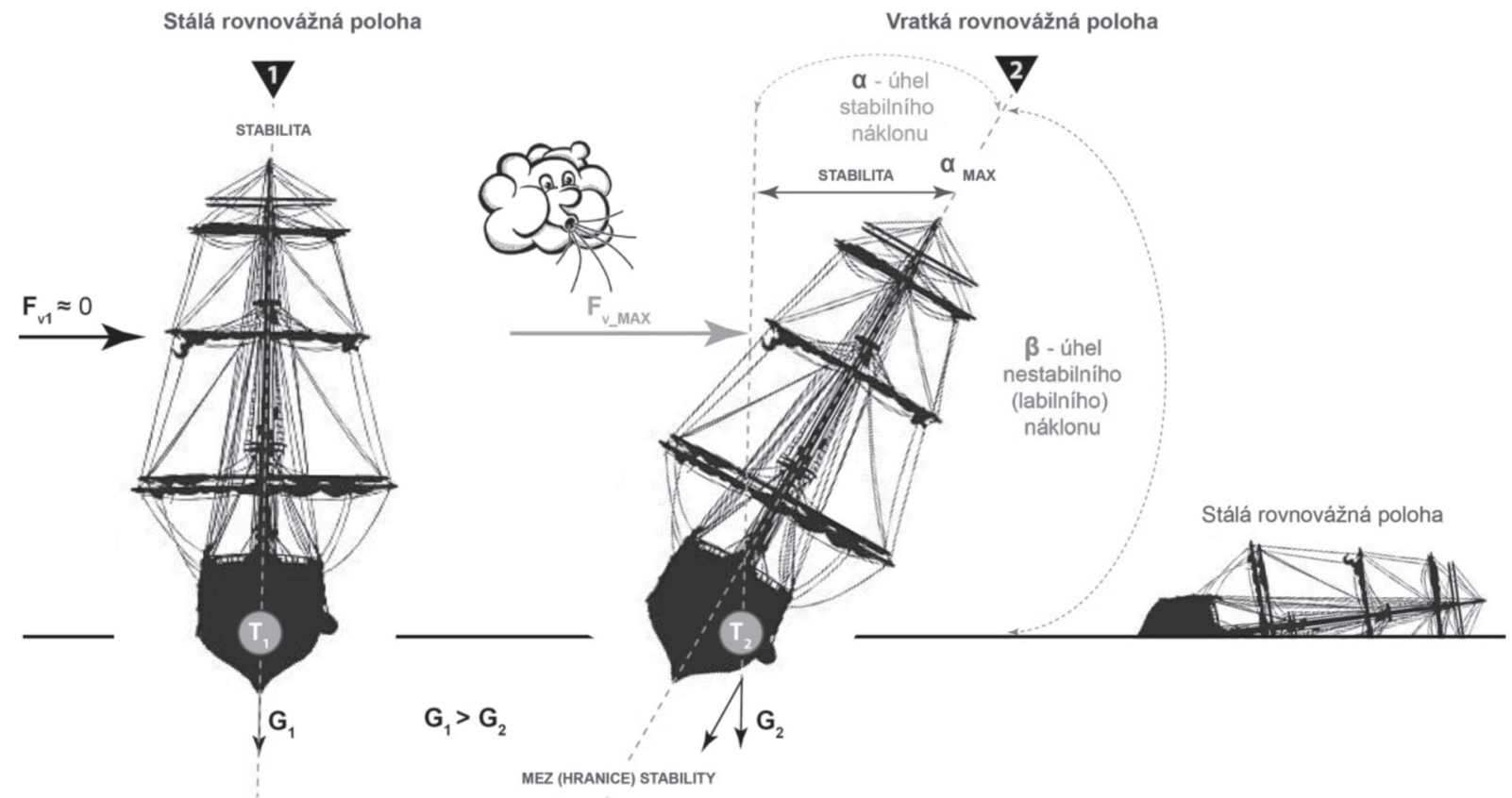

Obr. 4 Ztráta stability plachetnice jako přiklad působení významných vnějších faktorů na rovnovážný stav, rovnovážnou polohu.

Fig. 4 Loss of sailboat stability as an example of the effect of significant external factors on equilibrium, equilibrium position.

to je množství práce, které je třeba vykonat, aby se těleso ze stálé rovnovážné polohy dostalo do vratké rovnovážné polohy.

Stabilita tělesa závisí př́mo úměrně na hmotnosti tělesa, nepřímo úměrně na výšce těžiště ve stálé poloze a přímo úměrně na výšce těžiště ve vratké poloze.

V ostatních fyzikálních oborech (jako je optika, chemie, fyzika, elektrotechnika atd.), je stabilita definována jako schopnost udržování určitých vlastností beze změny v čase, $v$ humanitních oborech, jako je lingvistika, politika apod. jde o stálost vazeb v čase, které udržují systém ve své celistvosti.

V technickém prostředí je stabilita obvykle definována i jako schopnost zotavit se z poruch, nerovnovážných stavů, tj. vrátit se do stavu rovnovážného pro daný objekt, proces nebo systém. Príklad:

Stabilitou letadla se rozumí schopnost letadla zachovávat režim letu, do kterého jej pilot uvedl. Pokud by letoun nemél schopnost stability, $v$ určitých režimech letu by se nenechal pilotovat a došlo by $k$ bezpečnostni události - ke zrícení letadla.

V praxi hovoříme o stabilitě mechanických soustav, chemických či termodynamických dějů, geologické stabilitě podloží, stabilitě měny, společenské, politické, ekonomické stabilitě, stabilitě našich finančních př́jmů, stabilitě zdravotního stavu apod. [13].

Príklad:

Stabilitu si můžeme vysvětlit na př́kladu plachetnice, na kterou fouká boční vítr o síle $F_{v}$ Významnými parametry pro ztrátu stability plachetnice jsou síly bočního větru, položení těžiště plachetnice $T$ (konstrukční řešení, upevnèní nákladu), schopnost kapitána a posádky manévrovat s lodí.

Do určité maximálni síly větru $F_{v}$ MaX se stěžeň nakláni o úhel $\alpha$. Jestliže je náklad plachetnice v pō̄palubí nedostatečně připevnèn, náklonem plachetnice se bude pohybovat a tím se změni i těžiště plachetnice do polohy $T_{2}$. Pokud je tento úhel $\alpha<\alpha_{M A X}$, a silla větru se sniží, náklon stožáru plachetnice se bude sám, automaticky vracet do pưvodní, svislé, rovnovážné polohy. Pokud se sila větru bude ale zvětšovat nad hranici $F_{v}$ MAX , dojde $k$ nestabilitě plachetnice a ta se prevrátí na bok. $Z$ této nové rovnovážné polohy se již sama nevrátí do pưvodni svislé stabilní polohy plachetnice. Kapitán, aby se lod' nepřevrátila, musí realizovat tato opatření: nejtěžši náklad umist'ovat co nejhlouběji do podpalubí, ten dobre, upevňovat; v př́padě silného bočního větru lodí manévrovat tak, aby byl eliminován bočni vitr a ten změnou polohy lodi foukal co nejvice zezadu; nebo podkasat (svinout) plachtoví. Silný boční vitr je vždy zásadní zménou vnějšiho prostředí plachetnice.

Stabilita objektu, systému nebo procesu závisí na mnoha jejich specifických vlastnostech, jako jsou odolnost, imunita, pružnost, výdrž, trvanlivost apod. vůči určitým (normálním i vysloveně negativním) jevům, událostem, působícím silám, obecně působícím faktorům. Zároveň stabilita může silně záviset na charakteru (velikosti, směru, dynamičnosti, intenzitě, specifičnosti apod.) působících faktorů na sledované objekty, systémy či procesy [17]. Stabilita je relativní, pružná rovnováha, odolnost vůči určitému vychýlení od rovnovážného stavu, rovnovážné polohy.

Každá stabilita má v reálném světě svou určitou mez, hranici, dobu trvání, kdy objekty, systémy či procesy přestávají být stabilní a začnou být labilní (nestabilní), se všemi jejich negativními, bezpečnostními aspekty a jejich dopady [19].

Stabilita může být velmi relativní pojem - některé objekty, systémy či procesy se nemění během života jednoho lidského jedince, jiné objekty se stávají nestabilními (labilní) během zlomku vteřiny [22].

V procesu analýzy hrozeb, zranitelnosti, rizik, bezpečnosti [14] se často zabýváme analýzou vlastností, charakteristik objektů, systémů či procesů, které jsou předmětem našeho zájmu. $Z$ tohoto důvodu je nutné pozornost věnovat všemu, ve všech souvislostech, co má vliv na jejich stabilitu/labilitu. Naším cílem je obvykle zachovat co největší stabilitu, abychom se vyhnuli i potenciálním 


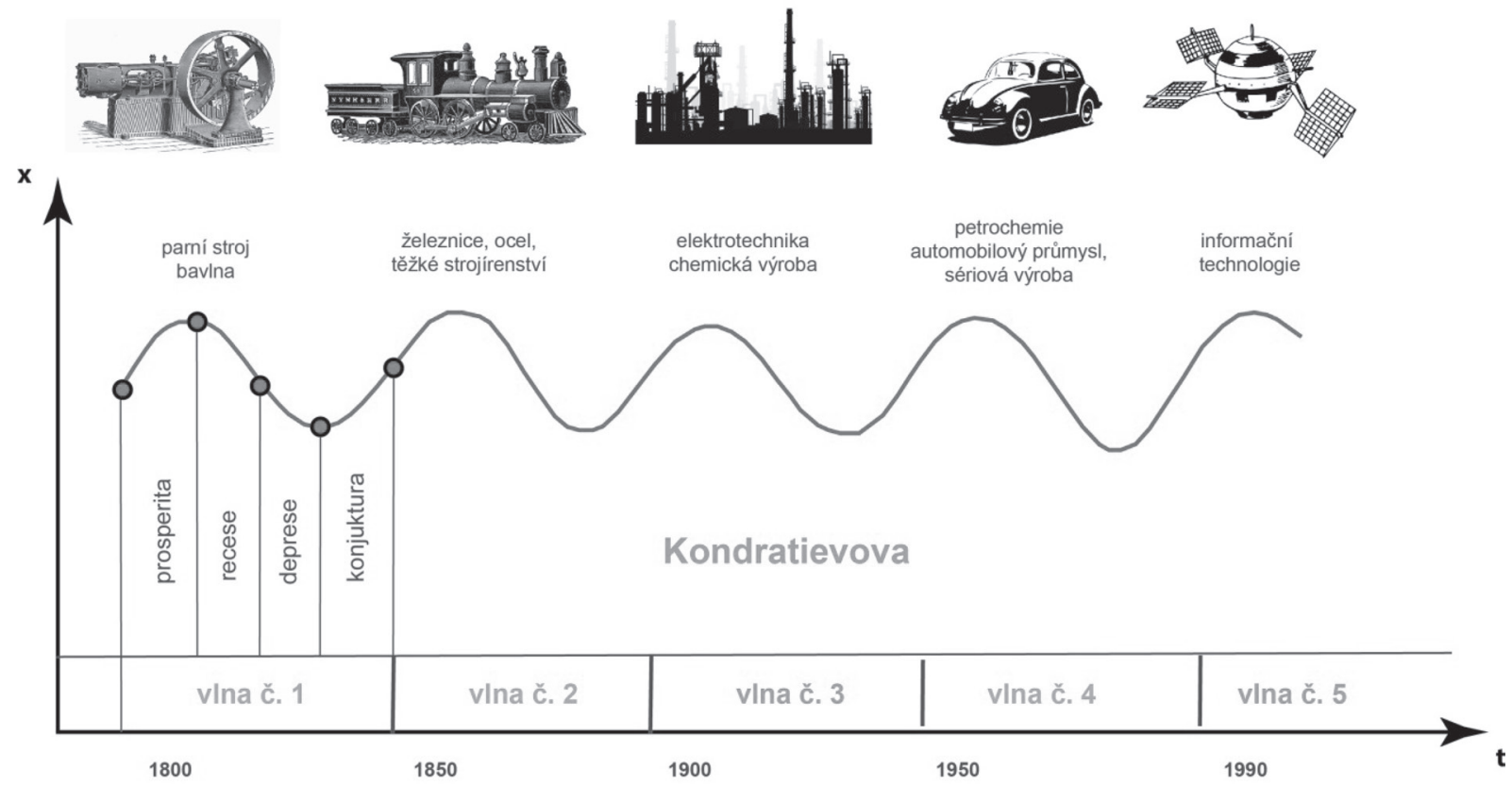

Obr. 5 Světová ekonomika se vyvijí v hospodářských cyklech. Pravidelně, periodicky se měni fáze prosperity, recese, deprese a konjuktury. Kondratievi̊v cyklus se méni prüměrnè v padesátiletých periodách. Podobných cyklů je v ekonomice více, liší se autor od autora zejména $v$ definici, objasñujicí príčiny prosperity - v poslednich 200 letech to byly vynálezy v oblasti techniky, které podnitily poptávku obyvatelstva po novém zboží, jež se vyrábělo ve velkých sériích. Periody stability a lability se cyklicky střídají.

Fig. 5 The world economy is developing in business cycles. Periodically, phases of prosperity, recession, depression and conjuncture change. The Kondratiev cycle changes on average over 50 years. There are more cycles of this kind in the economy, and the author in particular differs in the definition that explains the causes of prosperity - in the last 200 years, these were inventions in the field of technology that prompted the population's demand for new goods produced in large series. The periods of stability and lability alternate cyclically.

bezpečnostním jevům, událostem, rozporům, konfliktům, krizím [23],[25] apod.

Stabilitu (lat. stabilis - stálý, trvalý, pevný) můžeme obecně charakterizovat jako vlastnost, schopnost objektu, systému nebo procesu automaticky si udržovat v čase své stálé, základní charakteristiky, významné parametry, určující rovnovážný stav, rovnovážnou polohu nebo rovnováhu, celistvost, strukturu, funkčnost, komplexnost či jiné další významné vlastnosti objektu, systému či procesu nebo při vychýlení se z rovnovážného stavu se v určitém čase automaticky vrátit zpět do původního rovnovážného stavu, polohy či rovnováhy.

\subsubsection{Stabilita ekosystému (Stability of the ecosystem)}

Stabilita ekosystému - schopnost ekosystému vyrovnávat změny způsobené vnějšími činiteli a zachovávat své podstatné struktury a funkce. Tato schopnost se projevuje bud' tím, že změny v ekosystému, vyvolané rušivým vlivem, jsou relativně velmi malé (rezistence), anebo tím, že po odeznění rušivého vlivu se ekosystém bud' spontánně vrací do výchozího stavu, nebo - dojde-li k trvalé změně některých jeho vlastností - alespoň na původní vývojovou trajektorii (resilience). Nepůsobí-li rušivý vliv, pak se stabilní ekosystém bud' nemění, resp. mění jen velmi málo (konstantnost), nebo jsou jeho změny přibližně pravidelné (cykličnost). Nejtypičtěji se stabilita ekologická projevuje ekologickou rovnováhou.

\subsubsection{Stabilita sociální (Stability social)}

Stabilita sociální - rovnovážný stav sociálního systému, kdy jeho změna má podobu postupné adaptace na změny podmínek a prostředí. Dosažení takového stavu stojí od počátku v centru zájmu sociologie. Teorie sociologie řeší problém sociální stability např. v úvahách o optimálním vztahu činitelů sociální statiky a sociální dynamiky, aplikovaná sociologie chce přispět ke zvýšení sociální stability řešením konkrétních soc. problémů, popř. inženýrskými zásahy do oblasti soc. vztahů. Naléhavost zajištění sociální stability vzniká právě v moderní společnosti, která nahradila tradici, tedy vysoce účinný stabilizující faktor, potřebou neustálé inovace. Jestliže sociální stabilita tradiční společnosti měla obvykle blízko k sociální stagnaci, moderní stability nemá být dosaženo na úkor změny, nýbrž tím, že jsou vytvářeny vhodné podmínky pro regulaci průběhu změn. Otázka sociální stability [9], která v teoretické rovině nepředstavuje větší problém, patří $\mathrm{k}$ nejvážnějším problémům praktické politiky. Zatímco totalitní systémy zajišt'ují sociální stabilitu umrtvením občanské společnosti, demokratické společnosti vykupují do značné míry svoji sociální stabilitu nadměrným konzumem dostupným většině populace.

\subsubsection{Stabilita ekonomická (Economic stability)}

Stabilita ekonomická - stav vyjadřující existenci předpokladů, za nichž po každém vnějším narušení ekonomické rovnováhy dochází $\mathrm{k}$ jejímu obnovení bud' v původní podobě, anebo v podobě nové rovnováhy. Jestliže jakékoli velké vychýlení z rovnováhy vyvolá síly, které vrátí systém do rovnovážného stavu, mluví se o globální stabilitě. V př́ípadě menších odchylek jde o lokální stabilitu.

Pod pojmem ekonomické stability chápeme stálý růst reálného hrubého národního produktu, cenovou stabilitu a udržování 
nezaměstnanosti na úrovni přirozené nezaměstnanosti. To znamená, že produkt by měl růst rovnoměrně a takovým tempem, aby se zajistila cenová stabilita a dostatečná zaměstnanost.

\subsubsection{Stabilita finanční (Stability financial)}

Stabilita finanční neboli stabilita finančního systému je stav finančních trhů v ekonomice, který brání vzniku systémového rizika, tj. rizika, že poskytování nezbytných finančních produktů a služeb finančním systémem bude narušeno do té míry, že to může významně ovlivnit hospodářský růst a blahobyt. Vznik možných systémových rizik ve finančním systému je řešen prostřednictvím makroobezřetnostních politik, jejichž cílem je právě zachování finanční stability.

Česká národní banka definuje finanční stabilitu jako situaci, kdy finanční systém plní své funkce bez závažných poruch a nežádoucích důsledků pro současný i budoucí vývoj ekonomiky jako celku a zároveň vykazuje vysokou míru odolnosti vůči šokům.

\section{NESTABILITA JAKO BEZPEČNOSTNÍ RIZIKO (INSTABILITY AS A SECURITY RISK)}

Každá skutečnost, činnost, děj nebo jev, které probíhají v př́rodě, ve společnosti, v ekonomice, $v$ technologických procesech apod. stabilním způsobem, se mohou zpravidla kdykoliv změnou vnějších nebo vnitřních podmínek stát nestabilními (labilním), rizikovými a pro subjekty nekontrolovatelnými s reálnou možností způsobit člověku, skupinám obyvatelstva, institucím, firmám, společnosti či státu škody nebo újmy; ztráty. Pokud však člověk pochopí příčiny změn v objektech, systémech či probíhajících procesech, pokud je schopný včas odhalit jejich příznaky, může hledat cesty eliminace nebo minimalizace hrozeb (nebezpečí), cesty snižování rizik vzniku bezpečnostních událostí, krizových jevů; eliminovat tyto negativní jevy ještě před jejich působením na objekty, systémy či procesy. Odhalování a průběžné monitorování parametrů, které se stávají krizovými faktory pro danou skutečnost, umožňuje zabránit negativním dopadům a dosáhnout zodpovídající úroveň bezpečnosti [24].

\section{MEZNÍ STAVY (BOUNDARY STATES)}

Pojem mezní stav je nadoborový pojem, který můžeme aplikovat $\mathrm{v}$ různých oborech lidské činnosti (včetně bezpečnosti), na různé entity - na artefakty vytvořené člověkem, nebo na živé či neživé „produkty“ vývoje naší planety Země. Obecně je mezní stav časový okamžik, kdy dochází k zásadnímu narušení entity (objektu, procesu či systému), $\mathrm{v}$ důsledku které dochází ke ztrátě původní funkčnosti entity. Mezní stavy jsou aplikovatelné na člověka, společnost, výrobky a produkty, na technické, přírodní či společenské entity, na morálku [8] apod.

Znalost existence problematiky mezních stavů je velmi významná i v bezpečnosti [15]. $\mathrm{V}$ procesech analýzy rizik a při návrhu protiopatření pracujeme s různými entitami (objekty, procesy, systémy). Obvykle při analýzách vycházíme ze standardních, případně přechodových stavů těchto entit, kdy nehrozí žádné reálné hrozby; entity jsou dlouhodobě v rovnovážném, stabilním stavu. Mnohdy si neuvědomujeme mezní stavy analyzovaných entit, které v okamžiku jejich naplnění zcela změní vlastnosti, chování a funkčnost. Nastává situace, kdy nedokážeme zajistit bezpečnost na požadované úrovni, protože se entita zásadním způsobem v důsledku svého mezního stavu změnila; přestala plnit svou původně zamýšlenou funkci, činnost.

Mezní stavy, podle typu entity, na níž nastávají, můžeme dělit na [10]:

- Mezní stavy v technice nastávají u technických objektů, jsou to tedy mezní stavy technických objektů. Důvody, vyřazení technického objektu z funkce lze členit na technické (př́iciny interní; odpovídají technické mezní stavy) a technickoenvironmentální (příčiny externí, odpovídají technickoenvironmentální stavy).

- Mezní stavy př́írody (též ekologické, environmentální mezní stavy). Tyto mezní stavy nastávají u prrírodních objektů. Ekologické mezní stavy mohou nastávat na různě velkých lokalitách. Mohou mít charakter lokální, velkoplošný či globální. Mohou být způsobeny nevhodnými zásahy člověka do přírody (např. melioračními, chemizací hnojením, přípravky proti nežádoucí flóře a fauně, stavebními úpravami - přehrady, dálnice, toxickými skládkami), nevhodným působením technických objektů na přírodu (exhalace, znečišt'ování ovzduší, půdy a vod. Př́ćcinou může být i samostatná příroda - tornáda, zemětřesení, tsunami, záplavy; vesmír - srážky s vesmírnými tělesy atd.

- Mezní stavy člověka (živé bytosti). Objektem je v tomto př́ípadě člověk, kterého můžeme charakterizovat jeho materiálním tělem, nehmotným duševnem a interakcemi se svým okolím, tedy s lidmi, jimi vytvořenými artefakty, přírodou a vesmírem. Osobnostní mezní stavy můžeme členit podle příčin, které je způsobují, a to:

- v člověku samotném - patří sem např́iklad zdravotní mezní stavy, jež souvisejí s tělesnými a duševními nemocemi; etické mezní stavy, které souvisí s jednáním člověka ve vztahu k lidem, jim vytvořeným artefaktům a přírodě,

- v okolí příslušného člověka - sem patří mezní stavy související s těmito faktory:

- odchod z pracovního poměru,

- neshody v zaměstnání, rodině, společenských či politických organizacích, sportovních, zájmových klubech atd.,

- pracovním přetížení - psychologické mezní stavy, syndrom vyhoření jedince (,bournout syndrom").

- Mezní stavy ekonomické. V prostředí ekonomiky je možné nalézt celou řadu entit (objektů, procesů, systémů) které za specifických podmínek dosahují svých mezních stavů; ve větší či menší míře ohrožujících ekonomickou bezpečnost (jedinců, institucí, firem, bank, pojišt'oven, leasingových společností, jednotlivých průmyslových odvětví, trhů, až po bezpečnost státu, státních útvarů či společenství). Ke sledovaným systémovým veličinám ekonomického (parametrům) charakteru patří např. ukazatele jako jsou výšky dluhů, půjček, úvěrů, hypoték, kredibilita, schopnost splácet úvěry, inflace, nezaměstnanost, kupní síla obyvatelstva, kurzy lokálních a světových měn, produktivita apod. Mezními ekonomickými stavy jsou pak např. platební neschopnost, sekundární platební neschopnost, osobní, firemní, státní bankrot, vymáhání dluhů apod. 
- Mezní stavy společenské, profesionální (společenské, profesionální mezní stavy). K nejrozšířenějšímu společenskému meznímu stavu patří revoluce. Jsou to kvalitativní mezní stavy charakterizované tím, že určitý společenský řád nemůže (nechce) dále plnit svou funkci. Podnět k revoluci obvykle nepřichází ,ze shora“, od vládnoucích, mocenských skupin, které se jej snaží udržet. Zdrojem revoluce je dlouhodobá nespokojenost velké části obyvatelstva. Podnět přichází „ze zdola“, „utlačovaní“ už nechtějí takto dál pokračovat. $\mathrm{Ne}$ ve všech př́padech musí dojít k revoluci. Nespokojenost se současným stavem $\mathrm{v}$ demokratických společnostech ovlivňuje politiku, volby do různých zastupitelských orgánů, stávky na různých úrovních, veřejné protesty atd., což patří k evolučním procesům (nikoliv tedy k revolučním)

- Mezní stavy morálky - patří sem především stav morálky a s ní související mezní stavy terorizmu, násilných náboženských expanzí atd..

\section{1 Členění mezních stavů podle jejich vlastností}

Mezních stavů se u různých objektů může celkově vyskytovat velmi mnoho, a proto je můžeme např. dělit [10]:

- Podle charakteru změn stavových veličin

- Kvalitativní mezní stavy - mezní stav nastane tehdy, jestliže hodnota (kvantita) některého ze stavových parametrů se stane pro funkci objektu nepř́ípustná.

- Kvantitativní mezní stavy - mezní stav nastane tehdy, jestliže se změní kvalita některého ze stavových parametrů tak, že neumožňuje funkci objektu.
- Podle časového průběhu jejich vzniku:

- Okamžité mezní stavy - vznik mezního stavu závisí pouze na okamžitých hodnotách stavových parametrů, které určují vznik mezního stavu.

- Kumulativní mezní stavy - vznik mezního stavu závisí na kumulaci (hromadění) změn ve vlastnostech struktury objektu v procesu postupného působení a ovlivňování objektu z jeho okolí. Nezávisí tedy na okamžitých hodnotách parametru tohoto působení a ovlivňování, ale na jejich časovém průběhu.

- Podle možné následnosti mezních stav:

- Vylučující se (disjunktivní) mezní stavy - dva mezní stavy jsou označovány jako „vylučující se“, může-li vzniknout pouze jeden z nich, takže druhý je pak stavem nedosažitelným (tedy nebude následovat).

- Příčinné (kauzální, následné) mezní stavy - dva mezní stavy se označují jako kauzální tehdy, jestliže vznik jednoho mezního stavu vytváří podmínky pro možný vznik druhého mezního stavu.

- Podle chování po odstranění aktivace objektu:

- Vratné mezní stavy - po odstranění aktivace objektu vyvolávající mezní stav, jeho důsledky odezní.

- Nevratné mezní stavy - následky dosažení mezního stavu zůstávají i po odstranění aktivací na objekt.

- Podle charakteru následků dosažení mezního stavu:

- Poruchové mezní stavy - dosažení mezního stavu způsobí poruchu, v důsledku níž sice objekt není schopen plnit svou funkci, ovšem po odstranění poruchy je objekt opět provozuschopný, se svou plnou, původní funkčností.

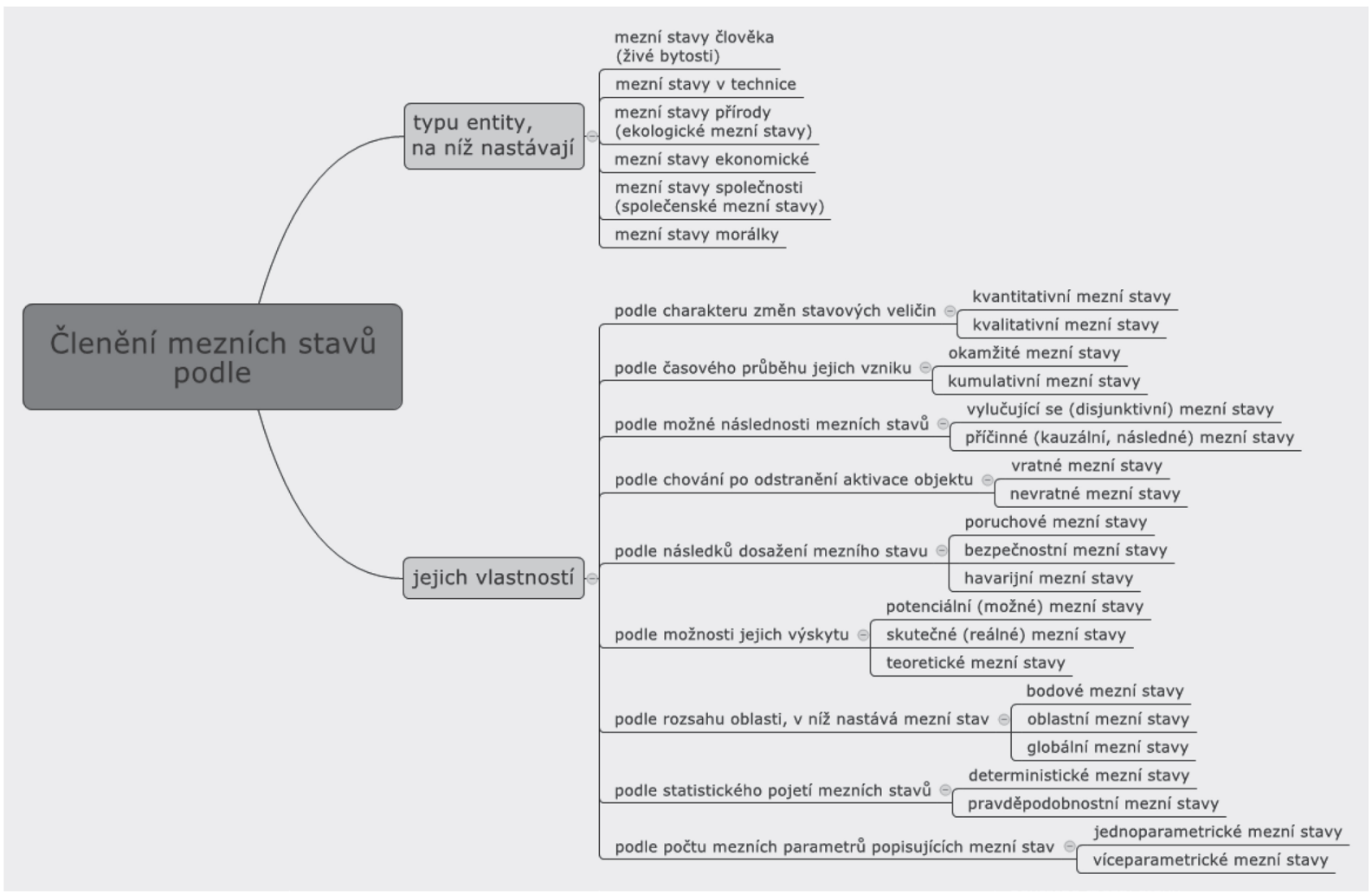

Obr. 6 Pohled na základní členění meznich stavů v podobě tzv. myšlenkové mapy.

Fig. 6 A view of the basic division of limit states in the form of the so-called mind map. 
- Bezpečnostní mezní stavy - souvisejí s bezpečností objektu. Dosažení mezního stavu způsobí destrukci součásti, která je součástí ochranného zařízení před vznikem havarijních stavů. Destrukce této „ochranné součásti“ ochrání objekt před vznikem jiných, mezních stavů.

- Havarijní mezní stavy - souvisejí s havárií objektu. Dosažení mezního stavu vede k destrukci objektu.

- Podle možnosti jejich výskytu.

- Podle rozsahu oblasti, v níž nastává mezní stav.

- Podle statistického pojetí mezních stavů:

- Deterministické mezní stavy - charakteristiky mezních stavů (mezní plochy) i charakteristiky spolehlivosti jsou určeny jednoznačně (kvantifikátor je určen jednou hodnotou).

- Deterministické mezní stavy - charakteristiky mezních stavů (mezní plochy) i charakteristiky spolehlivosti nejsou určeny jednoznačně (parametr je intervalové číslo).

- Podle počtu mezních parametrů popisujících mezní stav

- Jednoparametrické mezní stavy - mezní podmínka obsahuje pouze jeden mezní parametr. (např. varování o nezaplacení splátky hypotéky přijde v okamžiku, kdy uplyne doba 10 dní po termínu splátky.)

- Víceparametrické mezní stavy - mezní podmínka obsahuje více než jeden mezní parametr (např. voda začíná vřít při $100{ }^{\circ} \mathrm{C}$ a při tlaku $\left.1 \mathrm{~atm}\right)$.

\section{ZÁVĚR}

Problematika mezních stavů v systémovém pojetí při řízení bezpečnosti $\mathrm{v}$ obecném smyslu slova nebyla zatím $\mathrm{v}$ praxi široce využívána [11]. Mezní stavy jsou velmi dobře známé inženýrům, konstruktérům, projektantům zejména $\mathrm{v}$ oblasti strojírenství, stavebnictví, elektroenergetice, dopravě apod. Poznatky z mezních stavů lze ale obecně implementovat v podstatě na jakýkoliv objekt, pokud přihlédneme $\mathrm{k}$ jeho specifikům. Nemusí se jednat nutně jen o produkty, výrobky, ale teorie mezních stavů je aplikovatelná i do společenských [12], přírodních, bezpečnostních věd [2], [16]. Překonání mezních stavů, tj. ve své podstatě ztráty stability (technických i lidských objektů, systémů či soustav) jsou častými př́činami různých havárií, nehod či v globálnějším pohledu [1] i rozmanitých technických, společenských či prírodních katastrof.

\section{LITERATURA}

[1] AUGUSTIN, P., ODLER, R. The mission of the police in a democratic state in the context of globalization. Securitologia: czasopismo naukowe, pólrocznik, 2013. 18 (2), pp. 55-64. ISSN 1898-4509.

[2] BRUNOVA, M., RAK, R., Forensics characteristics of vehicle theft. In Porada V. et al: Criminalistics. Forensics science and cyber aspects. Plzen, Cenek, Czech Republic, 2019, pp. 10151023. ISBN 978-80-7380-741-2.

[3] BLAŽEK, V., DWORZECKI, J., BUZALKA, J. et al. Krízové scénáre vo verejnej správe. Akadémia Policajného zboru, Bratislava, 2016, 304 s., ISBN 978-80-8054-678-6.
[4] BOULDING, K. E. Conflict and Defense: A General Theory, Harper \& Row, New York 1962.

[5] DOUGHERTY, J. E., PFALTZGRAFF Jr., R. L: Contending Theories of International Relations, Addison-Wesley, New York, London 2001.

[6] EICHLER, J. Mezinárodní bezpečnost v době globalizace. Praha, Portál, 2009, 328 s., ISBN 978-80-7367-540-0.

[7] FELCAN, M. Problematika verejného poriadku ako jedna z najvýznamnejšich oblastí výkonu verejnej správy: kapitola č. 3 / aut. Miroslav Felcan: In: Aktuálne problémy vo verejnej správe EÚ / Kristína Králiková, Mária Sabayová a kol. - Bratislava: Akadémia Policajného zboru v Bratislave, 2016. s. 41-60. ISBN 978-80-8054-712-7.

[8] HENDRYCH, Dušan et al. Právnický slovník. 3. vyd. Praha: Beck, 2009. 1459 s., ISBN 978-80-7400-059-1.

[9] JANDOUREK, Jan. Sociologický slovník. Vyd. 1. Praha: Portál, 2001, s. 128. ISBN 80-7178-535-0

[10] JANÍČEK, P. Systémové pojetí vybraných oborů pro techniky. Hledáni souvislostí. Díl 1., 682 s., Brno, VUT, 2007, ISBN 97880-724-555-6.

[11] KOLITSCHOVA, P., KERBIC, J., RAK, R. Forensic and technical aspects of vehicle identification labels. In: 11th International Scientific and Technical Conference on Automative Safety, Casta Papernicka, Slovakia, Apr 18-20, 2018, Web of Science Access Number: 000435296000046, 2018-07-09, 345 E $47^{\text {th }}$ ST, New York, USA, IDS Number: BK3OJ, ISBN 978-15386-4578-9

[12] KOPENCOVÁ, Dagmar. Kriminalita mládeže - vybrané př́ípady z praxe. In: III. kriminologické dny, Stanislava Hoferková, Tereza Raszková (eds.), vědecká konference. Hradec Králové: Univerzita Hradec Králové, Pedagogická fakulta, 2015, s. 33-46. ISBN 97880-7435-572-1

[13] MACEK, P., FILÁK, A. Základy teorie policejně-bezpečnostní činnosti, Praha 2004, s. 160.

[14] NOVOTNÝ, K., Slovnik vybraných pojmů vztahujicich se $k$ hodnocení rizik podle §132a odst. 3 zákoniku práce. Rožnov pod Radhoštěm: Rožnovský vzdělávací servis, 2000. 104 s.

[15] ODLEROVÁ, M. Informačno-technické prostriedky a operativino-pátracia činnost'. Zákon o Policajnom zbore: aplikačná prax. Pilsen: Vydavatelství a nakladatelství Aleš Čeněk, s.r.o., 2017., pp. 196-217. ISBN 978-80-7380-682-8

[16] RAK, R., KOLITSCHOVÁ, P. Zamyšlení nad základními pojmy bezpečnost a bezpečí. In.: PORADA, V. a BRUNA, E. (eds.). Bezpečná Evropa 2018. Sborník sdělení z IX. Ročníku mezinárodní vědecké konference. Praha: VŠFS, 2019, 546 s., ISBN 978-80-7408-185-9.

[17] RAK, R., KOPENCOVA, D., FELCAN, M. Objects and systems - Basic analytical security features. Zborník zo 14. Medzinárodného sympózia konaného dne 14.3. 2019 v rámci medzinárodného vel'trhu Security Bratislava 2019, Akadémia Policajného zboru v Bratislave, Bratislava, s. 212, s. 41-55. ISBN 978-80-8054-795-0.

[18] RAK, R., KOPENCOVA, D., Security threats, characteristics and phases. Zborník zo 14. Medzinárodného sympózia konaného dne 14.3. 2019 v rámci medzinárodného vel'trhu Security Bratislava 2019, Akadémia Policajného zboru v Bratislave, Bratislava, s. 212, , s. 72-85. ISBN 978-80-8054-795-0

[19] ROBINSON, J., A., SNYDER, R.C., Decision-making in International Politics. In: Kelman, H.C. (ed.) International Behavior: A social-psychological Analysis, New York, 1965, pp. 435-463.

[20] ROUBAL, O., Sociology of Branding: ,Just do it “ in the „No Limits" World. Communication Today, FMK UCM Trnava: Fakulta masmediálnej komunikácie Univerzity sv. Cyrila 
a Metóda, 2017, year. 8, No. 1, pp. 40-52. ISSN 1338-130X .

[21] ROUBAL, O., The duality of hedonism in the ambivalent world of polarities. European Journal of Science and Theology, Iasi: Technical University of Iasi, 2019, Year 15, No. 1, pp. 203-213. ISSN 1841-0464.

[22] SEKYROVA, J., KOPENCOVA, D., MANAS. R., Documentation methods of forensic crime scene, Czech Ministry of Interior, Prague, MV-39230-1/VO-2010, evidence number 9/2010

[23] ŠIMÁK, L. a kol. Terminologický slovnik krizového řizení, Žilina, 2006, s. 36, ISBN 80-88829-75-5.
[24] ŠIMÁK, L., Krizový manažment vo verejnej správe, Žilinská univerzita v Žiline, Fakulta bezpečnostního inženierstva, 2015, 259 s., ISBN 978-80-554-1165-1.

[25] ŠIMON, L. Policajno-bezpečnostná činnost, Bratislava, 2016, s. 149, ISBN 978-80-8054-686-1.

[26] RAK, R. Rovnovážné a mezní stavy v bezpečnosti a soudním inženýrství. In: XXVIII. Mezinárodní vědecká conference Soudního inženýrství ExFoS 2019, 24.-25. ledna, 2019 v Brně. ÚSI VUT v Brně, 2019, s. 600-614. ISBN 978-80-214-5708-9.

Správná citace:

RAK, R. Rovnovážné a mezní stavy v bezpečnosti a soudním inženýrství. Soudní inženýrství, 2019, 30(2), 40-48.

DOI: http://dx.doi.org./10.13164/SI.2019.2.40. ISSN 1211-443X. 